\title{
Botany
}

\section{Connecting plant species and natural products from the Canadian prairie ecological zone to biomedical knowledge}

\begin{tabular}{|r|l|}
\hline Journal: & Botany \\
\hline Manuscript ID & cjb-2021-0067.R1 \\
\hline Manuscript Type: & Review \\
\hline Author: & 14-Jul-2021 \\
\hline Komplete List of Authors: & $\begin{array}{l}\text { Molina, Layla; University of Lethbridge, Natural Product Laboratory } \\
\text { Allard, Haley K.; University of Lethbridge, Natural Product Laboratory } \\
\text { Kernéis, Sophie M.; Lethbridge College, Microbial Research Group } \\
\text { Golsteyn, Roy; University of Lethbridge, Natural Product Laboratory }\end{array}$ \\
\hline $\begin{array}{r}\text { Is the invited manuscript for } \\
\text { consideration in a Special } \\
\text { Issue? : }\end{array}$ & Ethnobotanea, Blackfoot Confederacy, First Nations, Secondary metabolites, \\
\hline &
\end{tabular}

\section{SCHOLARONE ${ }^{\text {M }}$ \\ Manuscripts}




\title{
Connecting plant species and natural products from the Canadian prairie ecological zone to biomedical knowledge
}

\author{
Layla Molina ${ }^{1}$, Haley K. Allard ${ }^{1}$, Sophie M. Kernéis ${ }^{2}$, and Roy M. Golsteyn ${ }^{1 *}$
}

1. Natural Product Laboratory, University of Lethbridge, Lethbridge, AB, T1K 3M4 Canada

2. Microbial Research Laboratory, Lethbridge College, Lethbridge, AB, T1K 1L6 Canada

*Corresponding author:

Roy M. Golsteyn

Natural Product Laboratory, Department of Biological Sciences, University of Lethbridge, Lethbridge, Alberta, T1K 3M4 Canada

Tel. 403-332-4553

E-mail: roy.golsteyn@uleth.ca

\section{Grant numbers:}

This work was supported by the Canada Foundation for Innovation [grant number 34542], and Natural Sciences and Engineering Council of Canada (NSERC) Discovery Grant [Grant number RGPIN-2017-04398]. Funding sources had no involvement in this research. 


\begin{abstract}
Natural products from plants in Canadian ecological zones are understudied. There are, however, sound scientific arguments to justify investigation of natural products from plant species found within these zones. We review a broad range of scientific and local literature describing the features of the Canadian prairie ecological zone and the Asteraceae taxonomical family. Species from Asteraceae are well represented in the prairie ecological system, although very few have been investigated for natural products with bio-medical properties. Data from a range of sources that address ecological interactions, abiotic features, and Traditional Knowledge provide a foundation for future scientific studies of plant natural products found within Canadian borders. We draw from discoveries of the Asteraceae family and one of its major classes of secondary metabolites, sesquiterpenes, to stimulate research of Asteraceae species in Canada.
\end{abstract}




\section{Keywords}

Alberta

Asteraceae

Blackfoot

First Nations

Herbivory

Natural products

Prairie

Secondary metabolites

Sesquiterpene lactones

Traditional Knowledge 


\section{Asteraceae natural products as sources of bioactive molecules}

Plants from the taxonomical family, Asteraceae, are historically and scientifically recognized as sources of beneficial natural products (metabolites), such as treatments for malaria (Artemisia annua L.) (Septembre-Malaterre et al., 2020), respiratory diseases (Echinacia spp.) (Barrett, 2003), use as sweetners (Stevia spp.) (Soejarto et al., 2019), or wellness (Achillea millefolium L.) (Benedek and Kopp, 2007). Primary metabolites are essential for growth and include well known chemical families such as proteins, carbohydrates, lipids, chlorins (chlorophylls), and nucleic acids. Secondary metabolites, such as flavonoids, alkaloids, or terpenoids, including sesquiterpenes, are not thought to have vital roles; instead they act as supportive metabolites that evolved from ecological pressures (Hartmann, 1996). Secondary metabolites may be critical for defensive strategies against herbivores or pathogens, plant-plant competitions, or beneficial interactions for plants such as the attraction of pollinators or symbionts. They may also have protective roles against abiotic stressors such as changes in temperature, light intensity, UV exposure, among others (Pavarini et al., 2012). It is noteworthy that the precise boundaries of primary and secondary metabolites are becoming blurred (Erb and Kliebenstein, 2020).

The Asteraceae, also known as Compositae family, is the largest family of flowering plants containing 32,913 species in 1,911 genera distributed around the world except for Antarctica (Garden, 2013). It was taxonomically divided into 11 subfamilies and 35 tribes by Panero and Funk (2002) after analysis of DNA sequence data of chloroplasts genes. It is a monophyletic family characterized by a special type of inflorescence called pseudanthium, flower head, or capitulum, where disc and ray florets are arranged on a receptacle centripetally and are surrounded by bracts that form the involucre. This family presents anthers fused in a ring with the pollen pushed out by the style, and achenes (cypselas) usually with a pappus (Figure 1). There is a large morphological variation among its members, existing annual and perennial herbs, shrubs, vines, or trees, and 
although they are more common in open areas, they can be found in almost every type of habitat from forests to high elevation grasslands (Panero and Funk, 2002).

Several Asteraceae species are well known because they contribute to our diets, such as lettuce (Lactuca sativa L.), chicory (Cichorium intybus L.), and artichoke (Cynara cardunculus var. scolymus L.). Within the category of medicinal plants, Artemisia annua from Asteraceae, is the source of artemisinin and its derivatives artesunate and dihydroartemisinin are major antimalarial drugs. The discovery that $A$. аnnua was able to inhibit malarial parasite growth and the subsequent isolation of the sesquiterpene lactone artemisinin is attributed to Dr. Tu Youyou (Miller and Su, 2011). For this discovery, Dr. Youyou was awarded the Nobel Prize in 2015 (Youyou, 2016). The best-known species of this family in the prairie ecological zone is the sunflower (Helianthus annuus L.).

We consulted natural product related databases (Sorokina and Steinbeck, 2020), including National Center for Biotechnology Information (PubMed, PubChem), Google Scholar, VASCAN, as well as numerous limited print publications that are cited herein. Scientific information about the biological and medical potential of prairie plant species, including those from Asteraceae is limited. We review information from a diverse set of sources that support continued investigation of Asteraceae species from the prairie ecological zone for natural products, especially secondary metabolites such as sesquiterpene lactones. Members of the Asteraceae family produce a wide range of other secondary metabolites including: monoterpenes, diterpenes, triterpenes, sesquiterpenes, polyacetylenes, flavonoids, phenolic acids, benzofurans, and coumarins (Zdero and Bohlmann, 1990). They do not produce major classes of alkaloids, only pyrrolizidine alkaloids are found in Senecioneae and Eupatorieae tribes. The accumulation of lactonized sesquiterpenes and polyacetylenes, as well as the presence of many highly oxidized compounds, have been 
recognized as unique chemical signatures for most of the members of this family (Zdero and Bohlmann, 1990). Therefore, these compounds may be responsible for the unique medicinal uses that have been attributed to this family.

Vascular plants in Canada have been enumerated using provincial boundaries. The province of Alberta, which overlaps with much of the prairie ecological zone, has 1636 native vascular plant species belonging to 123 families (Kershaw and Allen, 2020). A widely used taxonomical key developed by Packer and Moss (1983) reported 1475 native plant species in Alberta. It is reported that $55 \%$ of the species present in Alberta $\left(661,848 \mathrm{~km}^{2}\right)$ can be found in Waterton Lakes National Park $\left(505 \mathrm{~km}^{2}\right)$, which is nestled in the south west corner of the province but only covers $0.08 \%$ of the provincial surface area (Kuijt, 1982).

Documents of the Flora of North America have recorded 2413 Asteraceae species and 418 genera for the United States and Canada (Committee, 1993). The Database of Vascular Plants of Canada (VASCAN) currently reports 691 species of the Asteraceae family from 163 genera and 19 tribes of the 4 subfamilies Asteroideae, Cichorioideae, Carduoideae, and Mutisioideae distributed across the ecological zones (Brouillet et al., 2010). It includes plants having one or more of five statuses. The status of native is given when a taxon is present in a region as a result of natural processes and not human intervention. Taxa are considered introduced if they were established after European colonization for accidental or deliberate human activity. The status of ephemeral refers to taxa that recur in the wild in a near-annual basis, usually from cultivation, but is not permanent. The VASCAN database catalogues a taxon as excluded when it has been reported from a region but it is not established, or it was erroneously determined, and as extirpated if it was native to the region but it is now considered eradicated (Brouillet et al., 2010). From these 691 species, 332 are present in the prairie region (provinces of Alberta, Saskatchewan, and Manitoba) 
from 106 genera and 18 tribes. 245 species are native to this region, 58 introduced, 27 excluded, and 2 ephemerals. In Alberta, which includes the prairie ecological zone, there are 270 species from 91 genera and 16 tribes from the Asteraceae family: 207 natives, 51 introduced, 11 excluded, and 1 ephemeral. Table 1 lists the Asteraceae species present in the prairies and their status in this region. Presence can refer to either Alberta, Saskatchewan, Manitoba, or combinations thereof. It is striking that only 9 of these species are described in Health Canada's NHPD monographs, and of those, only 3 are native plants (Table 2). The biotic and abiotic conditions of the prairies as well as association with Traditional Knowledge provide support for investigation of the biomedical properties of this family.

\section{The prairie ecological zone}

The prairie ecological zone is one of the fifteen zones of Canada. It extends from the western edge of Alberta to the eastern edge of Manitoba and has its base in the Canada-United States border, comprising the northern extension of the Great Plains of North America (Marshall et al., 1999). It is characterized by relatively little topographic relief, grasslands, limited forests, and a sub-humid to semiarid climate (Figure 2). Despite a strong presence of agricultural activity, little research has been done regarding the potential biological activities of its native flora. Similar to other ecological zones in the biosphere, Asteraceae is one of the major botanical families in the prairies.

\section{Secondary metabolites and the prairie ecological herbivory}

Secondary metabolism in plants may have evolved to interact with molecular targets that affect physiological functions in competing organisms (e.g. microorganisms, non-host plants, animals) (Wink, 2003). These organisms, in turn, can develop adaptive responses constituting plant-animal interactions. This coevolutionary adaptation process has contributed to the multitude of bioactive 
compounds found in plants (Wöll et al., 2013). We focus on the prairie ecological zone because it is a region in which vascular plants and grazing herbivores have co-existed since the Eocene Epoch $(45,000,000$ years ago) (Stebbins, 1981). In modern times, the prairies were occupied by vast herds of Bison bison (American bison, also known as buffalo), which are herbivores that weigh between 400-1,000 kg as adults. The bison were extirpated from Alberta by 1879 (Adams et al., 2004) and replaced immediately by domestic cattle. In 1880-1882 the number of cattle imported in Alberta increased from 1,352 to 16,282 with nearly 104,000 cattle registered by 1886 (Evans, 1978). There has been a nearly continuous grazing by herbivores on prairie grasslands (Mijaljica et al., 2012).

The bison had major effects upon prairie flora and contributed to patch dynamics, in which they reduce plant height, decrease grass numbers, and increase forb numbers (Myster, 2011). Grazing by large mammalian herbivores does reduce reproductive success and abundance yet increases diversity of prairie plant species (Spotswood et al., 2002, Bakker et al., 2006). Although much less studied, it was reported that below-surface organisms such as nematodes and mammals (Cynomys ludovicianus; prairie dogs) may be the largest contributor to herbivory in the United States grasslands (Ingham and Detling, 1984, Myster, 2011). It is not reported if the major belowsurface mammal in Canadian prairies, the ground squirrel, Urocitellus richardsonii, impacts below-surface herbivory.

Detailed examples of plant toxins affecting animal grazing are not common; the possum (Trichosurus vulpecula, a marsupial) alters its foraging behaviour relative to the concentration of plant toxin, eucalyptus oil, a terpene (Nersesian et al., 2011). The concept of adaptive plantherbivore behaviour in the prairie ecological zone is largely based on empirical data with little supportive experiment data to this day (Laycock, 1978, Briske, 1996). It would stand to reason 
that plants in grassland communities have developed significant secondary metabolites that affect animal physiology leading to avoidance (Briske, 1996). Some secondary metabolites produced by plants have a toxic effect in grazing animals. Grazing domestic animals are known to be at risk to intoxication by secondary metabolites from plant species within the prairie ecological zone, such as Thermopsis rhombifolia Nutt. ex Pursch (Fabaceae; buffalo bean) (Keeler et al., 1986, Keeler and Baker, 1990) or Delphinium nuttallianum Pritz. ex Walp. (Ranunculaceae; Larkspur) (Pfister et al., 1996). To support the agricultural development of the prairies, native plant species on the prairies have been investigated for toxicity at the whole animal level. In the province of Alberta, 42 native plant species from forbs to trees have been identified as toxic to livestock (Majak et al., 2008). A document circulated by the Government of Alberta lists 133 introduced and native plant species or genera that are toxic to humans and livestock of which the greatest number were members of Asteraceae (Government of Alberta, 1995). Although the type of secondary metabolite and its toxic dose have been frequently identified, the mechanism of action (host target receptor) is usually not known.

More recently, in European grasslands (not North American prairie), it has been proposed that at low concentrations certain secondary metabolites may benefit grazing herbivores by providing antioxidant or anti-parasite properties (Poutaraud et al., 2017). Some grazing animals in North American ecological zones display a preference for a plant species over another. In studies of deer (Odocoileus) and their consumption of prairie Fabaceae species, Dalea purpurea Vent. was consumed in preference relative to Amorpha canescens Pursh. (Nisi et al., 2015). Changes in plant defenses over a period of 39 years were observed in the investigation of aphids and Arabidopsis thaliana L. (Brassicaceae) interactions in Europe (Züst et al., 2012). Albeit a study of insect herbivore, it provides biological evidence of an interaction that is consistent with the 
notion of similar outcomes with mammalian herbivores. The possibility of relationships between animals and plants likely harbouring secondary metabolites is supported by an investigation of foraging habits of pygmy rabbits (Brachylagus idahoensis) and plants of Artemisia spp (Sagebrush) (Ulappa et al., 2014). The presence of secondary metabolites negatively influenced the selection of foraging by this small herbivore.

There are several examples of co-evolution between diverse organisms in the prairie ecological zone that are astonishing in their specificity and reside under a theme of connectivity in biology. The monarch butterfly (Danaus plexippus) feeds on the toxic prairie plant, milkweed (Asclepias incarnata L. (Apocynaceae)) which protects the butterfly against parasites, such as Ophryocystis elektroscirrha (Smilanich and Nuss, 2019). An example of a vertebrate (avian) and Asteraceae species relationship in the prairie setting is shown with the sage grouse (Centrocersus urophasianus) and the silver sagebrush (Artemisia cana Pursh.) (Adams et al., 2004). The sage grouse is a silver sagebrush obligate, with $100 \%$ of its food requirement in winter provided by this plant. The plant also provides nesting sites and cover from mammalian predators. The Artemisia spp. are poisonous to livestock and humans (Alberta Agriculture, 1995) but the phytochemical relationship between sage-grouse and Artemisia spp. has not been identified. Secondary metabolites from the sesquiterpene lactone class that are assigned to defense mechanisms may also have roles in tissue specific development in seedlings, moving them to a primary metabolite role (Padilla-Gonzalez et al., 2016, Spring et al., 2020).

\section{Secondary metabolites and prairie abiotic features}

The abiotic features of an ecological zone impact the secondary metabolites that can be isolated from plants within that zone. The prairie ecological zone of Canada has a dramatic range of abiotic 
features. Over a 30-year period at a central site (Lethbridge, $\mathrm{AB}$ ) in the prairies, the maximum daily average temperature was calculated to be $26.1^{\circ} \mathrm{C}$, with the extreme of $39.4^{\circ} \mathrm{C}$. In the same period, the minimum daily average was $-12.1^{\circ} \mathrm{C}$ with the extreme $-42.8^{\circ} \mathrm{C}$, a temperature range of $81^{\circ} \mathrm{C}$ (Government of Canada, 2021). The temperature range varies per year, as does the number of days per year with temperatures above $-5^{\circ} \mathrm{C}$ during the past 50 years; ranging between 141 to 213 days. Similar wide variations are observed with season precipitation in the form of snow and rain. Over a 50-year period, the amount of precipitation ranged between 111 to $554 \mathrm{~mm}$. The mean daily insolation is $3.7-5.1 \mathrm{Wh} / \mathrm{m}^{2}$, the highest of the fifteen Canadian ecozones, with the greatest intensity occurring in June (Government of Canada, 2021b). The 20-year average of direct normal irradiation is $1,900 \mathrm{Wh} / \mathrm{m}^{2}$ in the prairie zone, in contrast to $1,300 \mathrm{Wh} / \mathrm{m}^{2}$ for most other ecological zones at the similar latitude. Abiotic conditions are known to affect secondary metabolite concentrations (Rodziewicz et al., 2014). It is likely that plants in the prairie ecological system vary their secondary metabolite concentrations and have co-evolved means to stabilize metabolite concentrations in response to abiotic variation. There are reports, however, of how abiotic features such light intensity affects the concentration of sesquiterpene lactones in the prototype prairie Asteraceae, (Helianthus annuus L.) (Spring et al., 1986) and that flavonoid synthesis correlates with latitude of the host plant (Jaakola and Hohtola, 2010).

\section{Prairie plants with medical and wellness properties}

As a result of connections to ecological systems plants may synthesize metabolites that are structurally similar to animal metabolites, such as hormones, signal transduction ligands, or neurotransmitters, and may affect human physiology due to the resemblance in potential target sites (Briskin, 2000). Natural products can potentially modulate cellular responses that are of interest in biological research or drug development. Furthermore, because some natural products 
have evolved to modify animal physiology, they have inherent medicinal properties, which contributes to their success as medicines (Newman and Cragg, 2020).

\section{Indigenous Knowledge and prairie plants}

The prairie ecological zone in Canada and the United States has been home since time immemorial to members of North American First Nation communities. One of these, known as the Niitsitapi People (Blackfoot Confederacy), uses prairie plant species for medicinal purposes. The Niitsitapi hold an oral tradition and exchanges with scientific communities are not frequent, but some information has been made available publicly for all communities. A regional publication from 1987 lists 185 species of plants that are recognized from Traditional Knowledge as having medicinal properties (Johnston, 1987). A publication from 1974 lists 100 plant species with medicinal properties used by two of the Niitsitapi tribes, the Kainai and the Pikanii, who are located in southern Alberta (Hellson, 1974). Some information about medicinal plants from the Kainai tribe has been shared in a website (Galileo Network Website, 2016), which provides recorded audio and written information about 61 plants.

Several plant species that are found in the prairies are also distributed in other ecological zones and are recognized as medicinal plants by First Nations from those regions. The Asteraceae family was well represented amongst the medicinal plants known to First Nation communities across North America (Shemluck, 1982). This listing included 474 species, of which it is noteworthy that scientifically well known Achillea and Artemisia species (Asteraceae) were widely used by different tribes for a large number of ailments; whereas other listed species, some which are found in the prairies such as Hymenopappus filifolius Hook (Asteraceae) are not described in biomedical literature. Medicinal plants from the boreal plain ecological zone in central and 
northern Alberta that are known to Cree peoples were reviewed in 1982 by an Elder, Dr. Anne Anderson (Anderson, 1982). The information collected by Dr. Anderson was further studied and described in a MSc thesis (Wood, 1996). Kindscher (1992) reported an ethnobotanical study of 203 prairie plant species present in the prairie ecological system of the United States (Kindscher, 1992). Other regions outside of the prairie ecological zone, but which harbour plant species that are established in the prairies are part of Traditional Knowledge from the Thompson First Nations (Central British Columbia) (Turner et al., 1990) and Wood Cree First Nations (Central Saskatchewan) (Leighton, 1985), and the First Nation communities of boreal forests in western Canada (Marles et al., 2012). An encyclopedic reference of 3000 plant species known in Traditional Knowledge to First Nation communities of North America, which includes the prairie zone and the Blackfoot Confederacy is described by Moerman (2009). A survey of the information about prairie plants reveals several themes about western scientific and Traditional Knowledge:

1. The majority of plant species are not described as Traditional medicine in printed sources. It is noteworthy that the information about medicinal plants in different public sources are only partially overlapping, suggesting that much knowledge remains to be shared or exchanged between western scientific and First Nation communities.

2. There are relatively few references to cancer treatments, consistent with the difficulty of detecting internal tumours (Moerman, 2009). For example, there are 523 references to treatment for eye afflictions compared to 55 for cancer.

3. Specifically to Traditional Knowledge of Niitsitapi communities, very few plant species with medicinal properties have been investigated by Western scientific methods.

4. Asteraceae species that are globally distributed such as Achillea millefolium (Yarrow) or Helianthus annuus (Sunflower) have also been identified by distant cultures in Europe and 
Asia and by Niitsitapi communities for their medicinal properties (Johnston, 1987, Moerman, 2009, Laws, 2015).

The relationship between Traditional Knowledge and Western biomedical information has been recognized in the investigation of natural products globally. It has been reported that inclusion of Traditional Knowledge in western scientific studies increases the success of finding pharmacologically important compounds (Balick, 1990). Incorporating Traditional Knowledge has not been widely used in investigation of plant species in the Prairie ecological zone (Kindscher, 1992), although there are a small number of studies performed in other zones. Uprety et al. (2012) analyzed 49 publications related with the medicinal uses of North American Aboriginal people, including Canada's First Nations, Metis, and Inuit, and reported 546 medicinal plant taxa used by Aboriginal people of the Canadian boreal forest. The anti-diabetic properties of plants known to the Cree First Nations led to the isolation of several compounds including those with specific enzyme targets in glucose metabolism (Muhammad et al., 2012, Nistor Baldea et al., 2011, Shang et al., 2015, Downing et al., 2019). A study comparing anti-fungal activity of plants in Eastern Canada revealed a greater activity in extracts prepared from species identified by Traditional Knowledge when compared to those selected without ethnobotanical information (Jones et al., 2000). Examples of considering North American ethnobotanical knowledge to find anticancer activity screening include testing 29 plants used by the Gwich'in First Nation (Northwest Territories and Yukon) (Deeg et al., 2012), and testing of two plants used by Indigenous Peoples in New Mexico USA (Daniels et al., 2006). The exchange of Aboriginal Traditional Knowledge to western scientific knowledge remains incomplete in Canada. Currently, there are no studies published in which Canadian Niitsitapi Traditional Knowledge of prairie plants was incorporated into a western scientific study. 
In countries other than Canada, Indigenous Traditional Knowledge has contributed to the discovery of anti-cancer compounds from a variety of chemical scaffolds (Khadem and Marles, 2011). Comparison of the success of drug screening programs using either unbiased selection of plant materials to ethnobotanical biased selection favours the inclusion of ethnobotanical knowledge. Kindscher and colleagues tested published medicinal plants and were able to detect anti-cancer activity in tests in vitro. Similar trends were observed in studies of bioactive plants from rainforests (Balick, 1990), midwestern regions of United States (Lewis and Elvin-Lewis, 1995), and British Columbia (McCutcheon et al., 1992, McCutcheon et al., 1995). The increase in successful discovery of active compounds might be due to Traditional Knowledge about the best harvest conditions which would include time of year, which part of the plant, and which plant within a population. Traditional Knowledge from other cultures, such as from Chinese Traditional medicine, was used to guide the investigation of 15 plant species that are distributed in both Canadian and Chinese ecological zones (Ramirez-Erosa et al., 2007). In this study, the plants collected in Canada were found to have similar properties to those reported for plants collected in China.

The best methods to exchange western scientific and Traditional Knowledge have yet to be established, although notable progress has been made. Guidelines to promote equitable knowledge exchange are proposed by Canadian Tri-Council research agencies and by public Canadian universities, including the University of Lethbridge, which is situated in the prairies and Treaty 7 ancestral lands. In addition to these guidelines, our laboratory has chosen to only investigate a Traditional Knowledge perspective of a plant if a member of a First Nations community performs experiments in the laboratory. 


\section{The majority of cancer drugs are derived from plant natural products}

A study of drugs from 1981 to 2019 revealed the leading contribution of natural products for drug development (Newman et al., 2000). If biologics and vaccines are removed from the 247 agents approved for anticancer therapy, $75 \%$ of the agents are natural small molecules, derivatives of them, or synthetic products that were developed to mimic natural products. Even if the synthetic mimics of natural products are not counted, $41 \%$ of the approved anticancer small molecules are natural products or their derivatives. Examples from this list include the anticancer agents and their derivatives: camptothecin, isolated from the tree Camptotheca acuminata Decne (Nyssaceae) (Wall and Wani, 1996); the Vinca spp. alkaloids, vinblastine and vincristine, from the periwinkle Catharanthus roseus L. (Apocynaceae); paclitaxel, isolated from the bark of the Pacific Yew tree Taxus brevifolia Nutt. (Taxaceae) (Cragg, 1998). Plant natural products have had an enormous impact in the discovery of anti-cancer drugs, as paclitaxel and its derivatives, and by inspiring cell cycle targets for new anticancer drugs (Newman et al., 2000).

\section{The majority of plants species have not been investigated for biomedical properties}

Only a small percentage of plants have been investigated for their bioactive properties. It is estimated that there are 383,671 vascular plant species identified in the biosphere (Lughadha et al., 2016), of which 10,636 vascular plant species are restricted geographically to North America (USA and Canada) (Ulloa Ulloa et al., 2017). Miller (2011) estimates that between 540 to 23,490 new drugs remain to be found from all plants in the biosphere (Miller, 2011). This estimate considers that discovery of 135 natural drugs resulted from the only 2,000 plant species that were chemically described are from about 60,000 species that had been screened. An uncertainty on these estimates is whether all species have additive potential to synthesize new compounds or 
whether they are somewhat chemically redundant. However, most plant screenings are conducted for one bioactivity and other uses are not investigated (Miller, 2011). Moreover, this estimation is only taking into account natural products approved for medicinal purposes.

There are arguments that suggest a sufficient number of plant species have been characterized to identify phytochemicals and further investigation is unlikely to discover new chemicals. There is a compelling example to suggest otherwise: the discovery of docetaxel, a natural product isolated from the English yew, Taxus baccata L. (Taxaceae) (Potier et al., 1994). Docetaxel is a member of the taxane class of natural products that has become one of most widely used anti-cancer treatments. Its discovery was inspired by the isolation of paclitaxel from the Pacific yew, T. brevifolia, whose distribution is limited to western Canada and the Northwestern United States (Goodman and Walsh, 2001, Potier, 2001). T. baccata, whose toxic properties have been known since antiquity, is restricted to the European continent and the perimeter of the Mediterranean Sea (Iszkuło et al., 2016). The two species are closely related yet distinct. Each produces taxanes that are also closely related but distinct and individually have improved the lives of millions of cancer patents (Figure 3). The two natural products bind to the same protein (tubulin) and inhibit cell proliferation (Schiff et al., 1979, Ringel and Horwitz, 1991) but they affect cancer cell lines differently (Verweij et al., 1994), have different pharmacokinetic profiles in patients (Kearns, 1997), and have different drug costs (Clegg et al., 2002). It is difficult to comprehend the magnitude of possibilities of natural products from plants, but as exemplified by paclitaxel and docetaxel, all natural products may need to be studied for their potential to affect human physiology or provide a benefit.

The biomedical properties of many of the vascular plants geographically restricted to North America and Alberta are not well studied. By contrasting examples, the species Achillea 
millefolium, which is present in Alberta prairies and globally distributed, was the topic of 679 publications referenced in the National Center for Biotechnology Information (NCBI/PubMed) as of January 2021. Whereas the species, Arnica fulgens Pursh (Asteraceae, Foothills arnica), a member of the well known Arnica genus and is abundant but geographically restricted to prairies, is not described in any biomedical publications.

\section{Sesquiterpene lactones}

The Asteraceae family is known for the production of a class of secondary metabolites called sesquiterpene lactones (Seaman, 1982). Sesquiterpene lactones (SLs) are compounds with a 15carbon backbone that includes a lactone group. Its biosynthesis starts from the union of three isoprene units, which are 5-carbon derivatives of the mevalonic acid, creating an acyclic farnesyl pyrophosphate (FPP), the simplest sesquiterpene structure.

Sesquiterpene lactones have been isolated from many plant families such as Apiaceae, Magnoliaceae, Acanthaceae, Solanaceae, Araceae, Euphorbiaceae, amongst others (Chadwick et al., 2013), but they can be found almost ubiquitously in the Asteraceae family. SLs are found predominantly in tissues attractive to herbivores, such as leaves, phyllaries, and achenes, and stored in glandular trichomes or laticifers to be secreted in the surface of these organs (Chadwick et al., 2013). A range of biological activities has been attributed to them, from allelopathy, insect feeding deterrent, antibiotic, antifungal, and antiparasitic, to allergenic, toxic, and antiproliferative effects in animal and human cells.

Sesquiterpene lactones have been shown to have cytotoxic effects in cancer cells (Picman, 1986, Ghantous et al., 2010) ; however, little research has been done regarding their mechanism of action leading to cell death. Our laboratory collected the information about previous research made with SLs reporting a cell cycle arrest and a compilation can be found in the review from 
Bosco \& Golsteyn (2017). Strikingly, all sesquiterpene lactones with described anti-mitotic activity to date were isolated from species from the Asteraceae family. We have identified and characterized seven species from the Asteraceae family that are predominant in the prairie ecosystem and have anti-mitotic activity (Bosco, 2017, Molina, 2018, Molina et al., 2021, Bosco et al., 2021). We believe that the anti-mitotic activity of SLs present in Asteraceae species is understudied and that more chemicals and plants need to be investigated. Table 1 provides a list of Asteraceae species for launching these studies. It is likely that this argument can be applied to other plant families and Canadian ecological zones for other biomedical activities, hinting at the vast potential of natural products that remain to be discovered. 


\section{Acknowledgements}

We thank Dr. Jennifer McCune (University of Lethbridge) and members of the Natural Product and Cancer Cell Laboratories for valuable discussions. We thank the following organizations and people for granting permission to collect plants on public or private lands: Alberta Environment and Parks, Alberta Tourism Parks and Recreation, City of Lethbridge, Mr. Michael Monaghan. This work was supported by the Canada Foundation for Innovation, Natural Sciences and Engineering Council of Canada (NSERC) Discovery Grant, Shell Canada Foundation and the University of Lethbridge. 
Competing interests: The authors declare there are no competing interests.

\section{Contributors' statement:}

LM: Investigation, Writing

HKA: Investigation, Writing

SMK: Conceptualization, Investigation, Writing

RMG: Conceptualization, Supervision, Funding acquisition, Writing 


\section{References}

Adams, B. W., Carlson, D., Milner, T., Hood, T., Cairns, B. \& Herzog, P. 2004. Beneficial grazing management practices for Sage-Grouse (Centrocercus urophasianus) and ecology of silver sagebrush (Artemisia cana) in southeastern Alberta. Technical Report, Public Lands and Forests Division. Alberta Sustainable Resource Development. Publ. T/049.

Adeleke, B. S. \& Babalola, O. O. 2020. Oilseed crop sunflower (Helianthus annuus) as a source of food: Nutritional and health benefits. Food Sci Nutr, 8: 4666-4684.

Alberta Agriculture. 1995. Poisonous Outdoor Plants. Edmonton, Alberta, Canada: Alberta Agriculture and Rural Development.

Anderson, A. 1982. Herbs of Long Ago: Kayas Muskekeya. Edmonton, AB.

Bakker, E. S., Ritchie, M. E., Olff, H., Milchunas, D. G. \& Knops, J. M. 2006. Herbivore impact on grassland plant diversity depends on habitat productivity and herbivore size. Ecol Lett, 9: 780-788.

Balick, M. J. 1990. Ethnobotany and the identification of therapeutic agents in the rainforest. In Ciba Foundation Symposium 154 - Bioactive Compounds from Plants Edited by D.J. Chadwick and J. Marsh. Wiley and Sons. pp. 22-31; discussion 32-39.

Barrett, B. 2003. Medicinal properties of Echinacea: a critical review. Phytomed, 10: 66-86.

Benedek, B. \& Kopp, B. 2007. Achillea millefolium L. s.l. revisited: recent findings confirm the traditional use. Wien Med Wochenschr, 157: 312-314.

Bijak, M. 2017. Silybin, a major bioactive component of milk thistle (Silybum marianum L. Gaernt.)- chemistry, bioavailability, and metabolism. Molecules, 22.

Bosco, A. 2017. A novel anti-mitotic activity on human cells by pulchelloid A, a compound isolated from the prairie plant Gaillardia aristata. MSc, University of Lethbridge.

Bosco, A., Kernéis, S., Hatzopoulos, G., Favez, T., Gönczy, P., Tantapakul, C., Maneerat, M., Yeremy, B., Williams, D. E., Andersen, R. J. \& Golsteyn, R. M. 2021. Pulchelloid A, a sesquiterpene lactone chemical isolated from the Canadian prairie plant, Gaillardia aristata, inhibits cells in mitosis. Mol Biol Rep, 48: 5459-5471.

Briske, D. D. 1996. Strategies of plant survival in grazed systems: a functional interpretation. In: HODGSON, J. \& ILLIUS, A. W. (eds.) The Ecology and Management of Grazing Systems. Wallingford, U.K.: CAB International.

Briskin, D. P. 2000. Medicinal plants and phytomedicines. Linking plant biochemistry and physiology to human health. Plant Physiol, 124: 507-514.

Brouillet, L., Coursol, F., Meades, S. J., Favreau, M., Anions, M., Bélisle, P. \& Desmet, P. 2010. $V A S C A N$, the database of vascular plants of Canada [Online]. Available: http://data.canadensys.net/vascan [Accessed March 2018].

Chadwick, M., Trewin, H., Gawthrop, F. \& Wagstaff, C. 2013. Sesquiterpenoids lactones: benefits to plants and people. Int J Mol Sci, 14: 12780-12805.

Clegg, A., Scott, D. A., Hewitson, P., Sidhu, M. \& Waugh, N. 2002. Clinical and cost effectiveness of paclitaxel, docetaxel, gemcitabine, and vinorelbine in non-small cell lung cancer: a systematic review. Thorax, 57: 20-28.

Cragg, G. M. 1998. Paclitaxel (Taxol): a success story with valuable lessons for natural product drug discovery and development. Med. Res. Rev., 18: 315-331.

Daniels, A. L., Van Slambrouck, S., Lee, R. K., Arguello, T. S., Browning, J., Pullin, M. J., Kornienko, A. \& Steelant, W. F. 2006. Effects of extracts from two Native American plants on proliferation of human breast and colon cancer cell lines in vitro. Oncol Rep, 15: $1327-1331$. 
de Almeida, A. B., Luiz-Ferreira, A., Cola, M., Di Pietro Magri, L., Batista, L. M., de Paiva, J. A., Trigo, J. R. \& Souza-Brito, A. R. 2012. Anti-ulcerogenic mechanisms of the sesquiterpene lactone onopordopicrin-enriched fraction from Arctium lappa L. (Asteraceae): role of somatostatin, gastrin, and endogenous sulfhydryls and nitric oxide. $\mathrm{J}$ Med Food, 15: 378-383.

Deeg, K., Eichhorn, T., Alexie, G., Kretschmer, N., Andersch, K., Bauer, R. \& Efferth, T. 2012. Growth inhibition of human acute lymphoblastic CCRF-CEM leukemia cells by medicinal plants of the West-Canadian Gwich'in Native Americans. Nat. Prod. Bioprospect, 2: 35-40.

Downing, A. D., Eid, H. M., Tang, A., Ahmed, F., Harris, C. S., Haddad, P. S., Johns, T., Arnason, J. T., Bennett, S. A. L. \& Cuerrier, A. 2019. Growth environment and organ specific variation in in-vitro cytoprotective activities of Picea mariana in PC12 cells exposed to glucose toxicity: a plant used for treatment of diabetes symptoms by the Cree of Eeyou Istchee (Quebec, Canada). BMC Complement Altern Med, 19: 137.

Erb, M. \& Kliebenstein, D. J. 2020. Plant secondary metabolites as defenses, regulators, and primary metabolites: The blurred functional trichotomy. Plant Physiol, 184: 39-52.

Evans, S. M. 1978. Stocking the Canadian Range. Alta Hist., 26: 1-8.

Flora of North America Editorial Committee. 1993. Flora of North America. North of Mexico, New York, NY, Oxford University Press.

Gailileo Educational Network, G. E. 2016. Nitsitapiisinni Stories and Spaces [Online]. Available: https://galileo.org/kainai/ [Accessed 18 January 2021 2021].

Ghantous, A., Gali-Muhtasib, H., Vuorela, H., Saliba, N. A. \& Darwiche, N. 2010. What made sesquiterpene lactones reach cancer clinical trials? Drug Discov Today, 15: 668-678.

Goodman, J. \& Walsh, V. 2001. The Story of Taxol: Nature and politics in the pursuit of an anticancer drug, Cambridge University Press.

Government of Alberta. Climate Almanac for Alberta [Online]. Available: http://agriculture.alberta.ca/acis/almanac.jsp [Accessed January 2021].

Government of Canada. Canadian Climate Normals 1981-2010 Station Data [Online]. Available:

https://climate.weather.gc.ca/climate_normals/results_1981_2010_e.html?searchType=st nProv\&lstProvince $=\mathrm{AB} \&$ txtCentralLatMin $=0 \&$ txtCentralLatSec $=0 \&$ txtCentralLongMin $=0 \&$ txtCentralLongSec $=0 \&$ stnID $=2263 \& \operatorname{dispBack}=0$ [Accessed January 2021].

Government of Canada. Photovoltaic Potential and Solar Resource Maps of Canada [Online]. Available: https://fgp-

pgf.maps.arcgis.com/apps/webappviewer/index.html?id=c91106a7d8c446a19dd1909fd93 $645 \mathrm{~d} 3$ [Accessed January 2021].

Haghi, G., Hatami, A., Safaei, A. \& Mehran, M. 2014. Analysis of phenolic compounds in Matricaria chamomilla and its extracts by UPLC-UV. Res Pharm Sci, 9: 31-37.

Hartmann, T. 1996. Diversity and variability of plant secondary metabolism: a mechanistic view. Entomologia Experimentalis Applicata, 80: 177-188.

Hellson, J.C., and Gadd, M. 1974. Ethnology of the Blackfoot Indians. National Museum of Man Mercury Series. Canadian Ethnology Service Paper No. 19. National Museums of Canada, Ottawa.

Hyam, S. R., Lee, I. A., Gu, W., Kim, K. A., Jeong, J. J., Jang, S. E., Han, M. J. \& Kim, D. H. 2013. Arctigenin ameliorates inflammation in vitro and in vivo by inhibiting the 
PI3K/AKT pathway and polarizing M1 macrophages to M2-like macrophages. Eur J Pharmacol, 708: 21-29.

Ingham, R. E. \& Detling, J. K. 1984. Plant-herbivore interactions in a North American mixedgrass prairie : III. Soil nematode populations and root biomass on Cynomys ludovicianus colonies and adjacent uncolonized areas. Oecologia, 63: 307-313.

Iszkuło, G., Pers-Kamczyc, E., Nalepka, D., Rabska, M., Walas, Ł. \& Dering, M. 2016. Postglacial migration dynamics helps to explain current scattered distribution of Taxus baccata. Dendrobiol., 76: 81-89.

Jaakola, L. \& Hohtola, A. 2010. Effect of latitude on flavonoid biosynthesis in plants. Plant Cell Environ., 33: 1239-1247.

Johnston, A. 1987. Plants and The Blackfoot, Lethbridge, Graphcom Printers, Limited.

Jones, N. P., Arnason, J. T., Abou-Zaid, M., Akpagana, K., Sanchez-Vindas, P. \& Smith, M. L. 2000. Antifungal activity of extracts from medicinal plants used by First Nations Peoples of eastern Canada. J Ethnopharmacol, 73: 191-198.

Kearns, C. M. 1997. Pharmacokinetics of the taxanes. Pharmacotherapy, 17: 105s-109s.

Keeler, R. \& Baker, D. 1990. Myopathy in cattle induced by alkaloid extracts from Thermopsis montana, Laburnum anagyroides and a Lupinus sp. J Comp Pathol, 103: 169-182.

Keeler, R. F., Johnson, A. E. \& Chase, R. L. 1986. Toxicity of Thermopsis montana in cattle. Cornell Vet. , 76: 115-127.

Kershaw, L. \& Allen, L. 2020. Vascular Flora of Alberta: An illustrated guide, Bolton, ON, Canada, Amazon Canada.

Khadem, S. \& Marles, R. J. 2011. Chromone and flavonoid alkaloids: occurrence and bioactivity. Molecules, 17: 191-206.

Kindscher, K. 1992. Medicinal Wild Plants of the Prairie, Lawrence, Kansas, University Press of Kansas.

Kuijt, J. 1982. A Flora of Waterton Lakes National Park, Edmonton, University of Alberta.

Laws, B. 2015. Fifty plants that changed the course of history, Richmond Hill, ON, Firefly Books Ltd.

Laycock, W. A. 1978. Coevolution of poisonous plants and large herbivores on rangelands. J. Range Manag., 31: 335-342.

Leighton, A. L. 1985. Wild plant use by the woods Cree (Nihithawak) of East-Central Saskatchewan. In: National Museum of Man Mercury Series. Canadian Ethnology Service Paper No. 101. National Museums of Canada, Ottawa.

Lewis, W. H. \& Elvin-Lewis, M. P. 1995. Medicinal plants as sources of new therapeutics. Annal Missouri Botan. Garden, 82: 16-24.

Linde, K., Barrett, B., Wölkart, Bauer, R., and Melchart, D. 2006. Echinacea for preventing and treating the common cold. Cochrane Database Syst. Rev. 2006 Jan 25;(1):CD000530. doi: 10.1002/14651858.CD000530.pub2

Lughadha, E. N., Goverts, R., Belyaeva, I., Black, N., Lindon, H., Allkin, R., Magill, R. E. \& Nicolson, N. 2016. Counting counts: revised estimates of numbers of accepted species of flowering plants, seed plants, vascular plants and land plants with a review of other recent estimates. Phytotaxa, 272: 82-88.

Majak, W., Brooke, B. M. \& Ogilvie, R. T. 2008. Stock-poisoning plants of Western Canada, Ottawa, Canada, Research Branc Agriculture Canada.

Marles, R. J., Clavelle, C., Monteleone, L., Tays, N. \& Burns, D. 2012. Aboriginal Plant Use in Canada's Northwest Boreal Forest, Edmonton, AB, Canada Forest Service. 
Marshall, I. B., Schut, P. H. \& Ballard, M. 1999. A national ecological framework for Canada: Attribute data. , Ottawa/Hull, Agriculture and Agri-Food Canada, Research Branch, Centre for Land and Biological Resources Research, and Environment Canada, State of the Environment Directorate, Ecozone Analysis Branch.

McCutcheon, A. R., Ellis, S. M., Hancock, R. E. \& Towers, G. H. 1992. Antibiotic screening of medicinal plants of the British Columbian native peoples. J Ethnopharmacol, 37: 213223.

McCutcheon, A. R., Roberts, T. E., Gibbons, E., Ellis, S. M., Babiuk, L. A., Hancock, R. E. \& Towers, G. H. 1995. Antiviral screening of British Columbian medicinal plants. J Ethnopharmacol, 49: 101-110.

Mijaljica, D., Prescott, M. \& Devenish, R. J. 2012. A late form of nucleophagy in Saccharomyces cerevisiae. PLoS One, 7: e40013.

Miller, J. S. 2011. The discovery of medicines from plants: A current biological perspective. Econ. Bot., 65: 396-407.

Miller, L. H. \& Su, X. 2011. Artemisinin: discovery from the Chinese herbal garden. Cell, 146: 855-858.

Moerman, D. E. 2009. Native American Medicinal Plants: An Ethnobotanical Dictionary, Oregon, Timber Press, Inc.

Molina, L. 2018. Antimitotic activity of six Asteraceae plant extracts and identification of the sesquiterpene lactone hymenoratin from the Canadian plant Hymenoxys richardsonii. MSc, University of Lethbridge.

Molina, L., Williams, D. E., Andersen, R. J. \& Golsteyn, R. M. 2021. Isolation of a natural product with anti-mitotic activity from a toxic Canadian prairie plant. Heliyon, 7: e07131.

Muhammad, A., Guerrero-Analco, J. A., Martineau, L. C., Musallam, L., Madiraju, P., Nachar, A., Saleem, A., Haddad, P. S. \& Arnason, J. T. 2012. Antidiabetic compounds from Sarracenia purpurea used traditionally by the Eeyou Istchee Cree First Nation. J. Nat. Prod., 75: 1284-1288.

Myster, R. W. 2011. Above-ground vs. below-ground interactive effects of mammalian herbivory on tallgrass prairie plant and soil characteristics. J. Plant Interact., 6: 283-290.

Nersesian, C. L., Banks, P. B. \& McArthur, C. 2011. Titrating the cost of plant toxins against predators: determining the tipping point for foraging herbivores. J Anim Ecol, 80: 753760.

Newman, D. J. \& Cragg, G. M. 2020. Natural products as sources of new drugs over the nearly four decades from 01/1981 to 09/2019. J Nat Prod, 83: 770-803.

Newman, D. J., Cragg, G. M. \& Snader, K. M. 2000. The influence of natural products upon drug discovery. Nat Prod Rep, 17: 215-234.

Nisi, A. C., Hernandez, D. L., English, L. P. \& Rogers, E. S. 2015. Patterns of selective herbivory on five prairie legume species. Am. Midl. Nat., 173: 110-121.

Nistor Baldea, L. A., Martineau, L. C., Benhaddou-Andaloussi, A., Arnason, J. T., Lévy, É. \& Haddad, P. S. 2011. Inhibition of intestinal glucose absorption by anti-diabetic medicinal plants derived from the James Bay Cree traditional pharmacopeia. J. Ethnopharmacol., 132: 473-482.

Omar, A. M., Dibwe, D. F., Tawila, A. M., Sun, S., Kim, M. J. \& Awale, S. 2019. Chemical constituents from Artemisia vulgaris and their antiausterity activities against the PANC-1 human pancreatic cancer cell line. Nat Prod Res: 1-7. 
Padilla-Gonzalez, G. F., dos Santos, F. A. \& Da Costa, F. B. 2016. Sesquiterpene lactones: More than protective plant compounds with high toxicity. Crit. Rev. Plant Sci, 35: 18-37.

Panero, J. L. \& Funk, V. A. 2002. Toward a phylogenetic subfamilial classification for the Compositae (Asteraceae). Proc Biol Soc Washington, 115: 909-922.

Pareek, A., Suthar, M., Rathore, G. S. \& Bansal, V. 2011. Feverfew (Tanacetum parthenium L.): A systematic review. Pharmacogn Rev, 5: 103-110.

Pavarini, D. P., Pavarini, S. P., Niehues, M. \& Lopes, N. P. 2012. Exogenous influences on plant secondary metabolite levels. Animal Feed Science Tech., 176: 5-16.

Pfister, J. A., Manners, G. D., Gardner, D. R., Price, K. W. \& Ralphs, M. H. 1996. Influence of alkaloid concentration on acceptability of tall larkspur (Delphinium spp.) to cattle and sheep. J. Chem. Ecol., 22: 1147-1168.

Picman, A. K. 1986. Biological activities of sesquiterpene lactones. Biochem System Ecol., 14: 255-281.

Potier, P. 2001. Le Magasin de Bon Dieu, France, J.C. Lattes.

Potier, P., Guéritte-Voegelein, F. \& Guénard, D. 1994. Taxoids, a new class of antitumour agents of plant origin: recent results. Nouv Rev Fr Hematol, 36 Suppl 1: S21-23.

Poutaraud, A., Michelot-Antalik, A. \& Plantureux, S. 2017. Grasslands: A source of secondary metabolites for livestock health. J Agric Food Chem, 65: 6535-6553.

Ramirez-Erosa, I., Huang, Y., Hickie, R. A., Sutherland, R. G. \& Barl, B. 2007. Xanthatin and xanthinosin from the burs of Xanthium strumarium L. as potential anticancer agents. Can. J. Physiol. Pharmacol., 85: 1160-1172.

Ringel, I. \& Horwitz, S. B. 1991. Studies with RP 56976 (taxotere): a semisynthetic analogue of taxol. J Natl Cancer Inst, 83: 288-291.

Rodziewicz, P., Swarcewicz, B., Chmielewska, K., Wojakowska, A. \& Stobiecki, M. 2014. Influence of abiotic stresses on plant proteome and metabolome changes. Acta Physiol Plantarum, 36: 1-19.

Royal Botanic Gardens Kew and Missouri Botanic Garden. 2013. The Plant List [Online]. Available: http://www.theplantlist.org [Accessed March 2018].

Schiff, P. B., Fant, J. \& Horwitz, S. B. 1979. Promotion of microtubule assembly in vitro by taxol. Nature 277: 665-667.

Seaman, F. C. 1982. Sesquiterpene lactones as taxonomic characters in the Asteraceae. Bot. Rev., 48: 121-595.

Septembre-Malaterre, A., Lalarizo Rakoto, M., Marodon, C., Bedoui, Y., Nakab, J., Simon, E., Hoarau, L., Savriama, S., Strasberg, D., Guiraud, P., Selambarom, J. \& Gasque, P. 2020. Artemisia annua, a traditional plant brought to light. Int J Med Sci, 21: 4986.

Shang, N., Saleem, A., Musallam, L., Walshe-Roussel, B., Badawi, A., Cuerrier, A., Arnason, J. T. \& Haddad, P. S. 2015. Novel approach to identify potential bioactive plant metabolites: Pharmacological and metabolomics analyses of ethanol and hot water extracts of several canadian medicinal plants of the Cree of Eeyou Istchee. PLoS One, 10: e0135721.

Shemluck, M. 1982. Medicinal and other uses of the Compositae by Indians in the United States and Canada. J. Ethnopharmacol., 5: 303-358.

Smilanich, A. M. \& Nuss, A. B. 2019. Unlocking the genetic basis of monarch butterflies' use of medicinal plants. Mole. Ecol., 28: 4839-4841.

Soejarto, D. D., Addo, E. M. \& Kinghorn, A. D. 2019. Highly sweet compounds of plant origin: From ethnobotanical observations to wide utilization. J Ethnopharmacol, 243: 112056. 
Sorokina, M. \& Steinbeck, C. 2020. Review on natural products databases: where to find data in 2020. J Cheminform, 12: 20.

Spotswood, E., Bradley, K. L. \& Knops, J. M. 2002. Effects of herbivory on the reproductive effort of 4 prairie perennials. BMC Ecol, 2: 2.

Spring, O., Priester, T. \& Hager, A. 1986. Light-induced accumulation of sesquiterpene lactones in sunflower seedlings. J. Plant Physio., 123: 79-89.

Spring, O., Schmauder, K., Lackus, N. D., Schreiner, J., Meier, C., Wellhausen, J., Smith, L. V. \& Frey, M. 2020. Spatial and developmental synthesis of endogenous sesquiterpene lactones supports function in growth regulation of sunflower. Planta, 252: 2.

Srinameb, B. O., Nuchadomrong, S., Jogloy, S., Patanothai, A. \& Srijaranai, S. 2015. Preparation of inulin powder from Jerusalem artichoke (Helianthus tuberosus L.) tuber. Plant Foods Hum Nutr, 70: 221-226.

Stebbins, G. L. 1981. Coevolution of grasses and herbivores. Annal. Miss. Botanic. Garden, 68: 75-86.

Street, R. A., Sidana, J. \& Prinsloo, G. 2013. Cichorium intybus: Traditional uses, phytochemistry, pharmacology, and toxicology. Evid Based Complement Alternat Med. 2013: 579319.

Turner, N. J., Thompson, L. C., Thompson, T. \& York, A. Z. 1990. Thompson Ethnobotany: Knowledge and usage of plants by the Thompson Indians of British Columbia, Victoria, BC, Royal British Columbia Museum.

Ulappa, A. C., Kelsey, R. G., Frye, G. G., Rachlow, J. L., Shipley, L. A., Bond, L., Pu, X. \& Forbey, J. S. 2014. Plant protein and secondary metabolites influence diet selection in a mammalian specialist herbivore. J Mammal, 95: 834-842.

Ulloa Ulloa, C., Acevedo-Rodriguez, P., Beck, S., Belgrano, M. J., Bernal, R., Berry, P. E., Brako, L., Celis, M., Davidse, G., Forzza, R. C., Gradstein, S. R., Hokche, O., Leon, B., Leon-Yanez, S., Magill, R. E., Neill, D. A., Nee, M., Raven, P. H., Stimmel, H., Strong, M. T., Villasenor, J. L., Zarucchi, J. L., Zuloaga, F. O. \& Jorgensen, P. M. 2017. An integrated assessment of the vascular plant species of the Americas. Science, 358: 16141617.

Verweij, J., Clavel, M. \& Chevalier, B. 1994. Paclitaxel (Taxol) and docetaxel (Taxotere): not simply two of a kind. Ann Oncol, 5: 495-505.

Wall, M. E. \& Wani, M. C. 1996. Camptothecin and taxol: from discovery to clinic. J Ethnopharmacol. 51: 239-254.

Wink, M. 2003. Evolution of secondary metabolites from an ecological and molecular phylogenetic perspective. Phytochem., 64: 3-19.

Wöll, S., Kim, S. H., Greten, H. J. \& Efferth, T. 2013. Animal plant warfare and secondary metabolite evolution. Nat Prod Bioprospect, 3: 1-7.

Wood, D. K. 1996. Scenes of togetherness: A Cree Elder's philosophy of health and healing. M.Ed., University of Alberta.

Youyou, T. 2016. Artemisinin - a gift from traditional Chinese medicine to the world (Nobel Lecture). Angewandte Chem Internatl Ed, 55: 10210-10226.

Zdero, C. \& Bohlmann, F. 1990. Systematics and evolution within the Compositae, seen with the eyes of a chemist. Plant Systematic Evol, 171: 1-14.

Züst, T., Heichinger, C., Grossniklaus, U., Harrington, R., Kliebenstein, D. J. \& Turnbull, L. A. 2012. Natural enemies drive geographic variation in plant defenses. Science, 338: 116119. 


\section{Figure Legends}

Figure 1. Botanical description of Asteraceae flower heads.

A. The key morphological features that characterize the flower heads of members of the Asteraceae taxonomical family are shown as a side view.

B. A side view of the flower from Gaillardia aristata Pursh (Blanket flower), which is a striking flower present in the prairie ecological zone that contains bioactive sesquiterpene lactones. Scale bar is shown.

C. A top view of the flower from G. aristata. Scale bar is shown.

Figure 2. The prairie ecosystem in Alberta, Canada.

This is an image of the prairie ecosystem in Alberta taken at $49^{\circ} 05 \mathrm{~N}$ and $112^{\circ} 28 \mathrm{~W}$ (approximately $100 \mathrm{~km}$ East of the Rocky Mountains and $15 \mathrm{~km}$ North of the Canadian-American border). The worn path around the boulder was made by grazing mammals and is a testimony to the herbivory that occurs in this region. The boulder is an erratic, deposited during the last ice age. It measures approximately 1.5 metres across. Although not visible, there are at least ten forb species that are present and blooming at time the photo was taken. Very few of these species have been investigated for the biomedical properties of their secondary metabolites.

Figure 3. The two best anti-cancer drugs are from two closely related plant species.

The chemical structures of paclitaxel (Taxol®, left) and docetaxel (Taxotere ${ }^{\circledR}$, right) are shown. The arrows point to functional groups that differ between the two natural products. Paclitaxel was first isolated from the plant species Taxus brevifolia (Pacific yew), which is distributed throughout British Columbia and present in Waterton National Park, Alberta. Docetaxol was first isolated 
from Taxus baccata (English yew) in France. The chemical structures are found in the National Center for Biotechnology Information website: https://pubchem.ncbi.nlm.nih.gov/compound/taxol and https://pubchem.ncbi.nlm.nih.gov/compound/Docetaxel. 
Table 1. Asteraceae family members in Canada according to the database of vascular plants (VASCAN). The status within the Prairie region is indicated in parenthesis as follows: native (N), introduced (I), ephemeral (EP), or excluded (EX).

\begin{tabular}{|c|c|c|c|}
\hline Subfamily & Tribe & Genus & Species \\
\hline \multirow{17}{*}{ Asteroideae } & \multirow{9}{*}{ Anthemideae } & Achillea & A. alpina L. (N), A. borealis L. (N). \\
\hline & & Anthemis & A. arvensis L. (1753) (I), A. cotula L. (I). \\
\hline & & Arctanthemum & A. $\operatorname{arcticum}(\mathrm{L}$.$) Tzvelev (\mathrm{N})$. \\
\hline & & Artemisia & 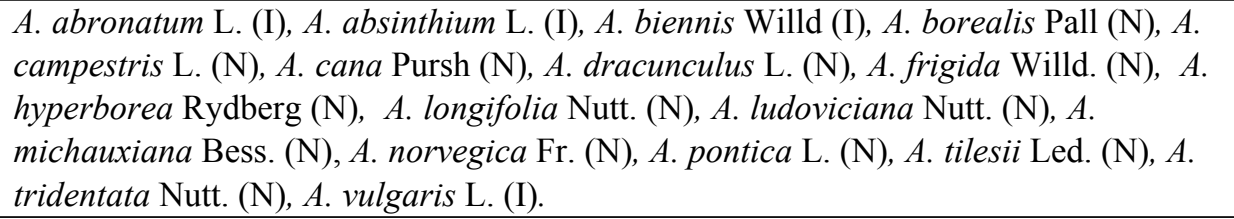 \\
\hline & & Cota & C. tinctoria L. (I). \\
\hline & & Leucanthemum & L. vulgare Lam. (I). \\
\hline & & Matricaria & M. chamomilla L. (I), M. discoidea DC.(I). \\
\hline & & Tanacetum & $\begin{array}{l}\text { T. balsamita L. (I), T. bipinnatum L. Sch. Bip. (N), T. parthenium L. Sch. Bip. (I), T. } \\
\text { vulgare L. (I). }\end{array}$ \\
\hline & & Tripleurospermum & T. inodorum L. Sch. Bip. (I). \\
\hline & \multirow[b]{8}{*}{ Astereae } & Almutaster & A. pauciflorus (Nutt.) Á. Löve \& D. Löve (N). \\
\hline & & Aster & A. alpinus L. $(\mathrm{N})$. \\
\hline & & Boltonia & B. asteroides (L.) L'Hér. (N). \\
\hline & & Canadanthus & C. modestus (Lindl.) G.L. Nesom (N). \\
\hline & & Dieteria & D. canescens Nutt. $(\mathrm{N})$. \\
\hline & & Doellingeria & $\begin{array}{l}\text { D. engelmannii (D.C. Eaton) Semple, Brouillet \& G.A. Allen (N), D. umbellate Nees } \\
\text { (N). }\end{array}$ \\
\hline & & Ericameria & E. nauseosa Pall. ex Pursh G.L. Nesom (N). \\
\hline & & Erigeron & $\begin{array}{l}\text { E. acris L. (N), E. annuus L. (N)), E. aureus Greene (N), E. caespitosus Nutt. (N), E. } \\
\text { canadensis L. (I), E. compositus Pursh (N), E. divergens Torr. A. Gray (N), E. elatus } \\
\text { Greene (N), E. evermannii Rydb. (EX), E. flagellaris A. Gray (N), E. formosissimus } \\
\text { Greene (EX), E. glabellus Nutt. (N), E. glacialis (Nutt.) A. Nelson (N), E. grandiflorus } \\
\text { Hook. (N), E. humilis Graham (N), E. hyssopifolius Michx. (N), E. lackschewitzii G.L. } \\
\text { Nesom W.A. Weber (N), E. lanatus Hook. (N), E. lonchophyllus Hook. (N), E. nivalis } \\
\text { Nutt. (N), E. ochroleucus Nutt. (N), E. pallens Cronquist (N), E. peregrinus Greene (N) } \\
\text { E. philadelphicus L. (N), E. pumilus Nutt. (N), E. radicatus Hook. (N), E. speciosus } \\
\text { (Lindl.) DC. (N), E. strigosus Muhl. ex Willd (N), E. trifidus Hook. (N), E. arthurii B. } \\
\text { Boivin (N). }\end{array}$ \\
\hline
\end{tabular}




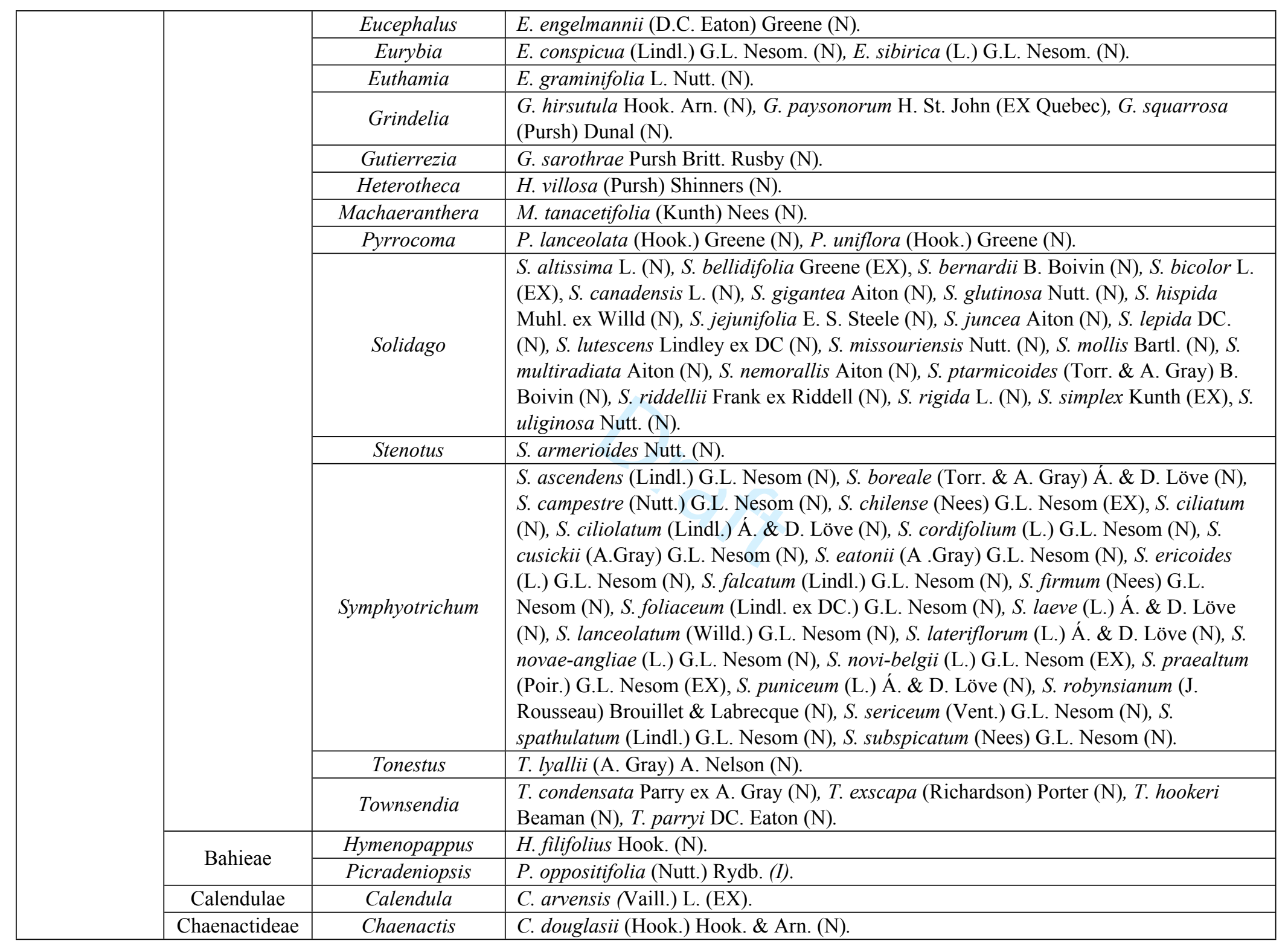




\begin{tabular}{|c|c|c|}
\hline \multirow{3}{*}{ Coreopsideae } & Bidens & $\begin{array}{l}\text { B. amplissima Greene (I), B. beckii Torr. ex Spreng. }(\mathrm{N}), \text { B. cernua L. (N), B. frondosa } \\
\text { L. }(\mathrm{N}), \text { B. tripartita L. }(\mathrm{N}), \text { B. vulgata Greene }(\mathrm{N})\end{array}$ \\
\hline & Coreopsis & C. tinctoria Nutt. (N). \\
\hline & Thelesperma & T. subnudum A. Gray (N). \\
\hline \multirow{6}{*}{ Eupatorieae } & Ageratina & A. altissima (L.) R.M. King \& H. Rob. (EX). \\
\hline & Brickellia & B. grandiflora (Hook.) Nutt. (N). \\
\hline & Conoclinium & C. coelestinum (L.) DC. (EP). \\
\hline & Eupatorium & E. perfoliatum L. (N). \\
\hline & Eutrochium & E. maculatum (L.) E.E. Lamont (N), E. purpureum (L.) E.E. Lamont (EX). \\
\hline & Liatris & L. aspera Michx. (EX), L. ligulistylis (A. Nelson) K. Schum. (N), L. punctata Hook. (N). \\
\hline \multirow{7}{*}{ Gnaphalieae } & Anaphalis & A. margaritaceae L. $(\mathrm{N})$. \\
\hline & Antennaria & 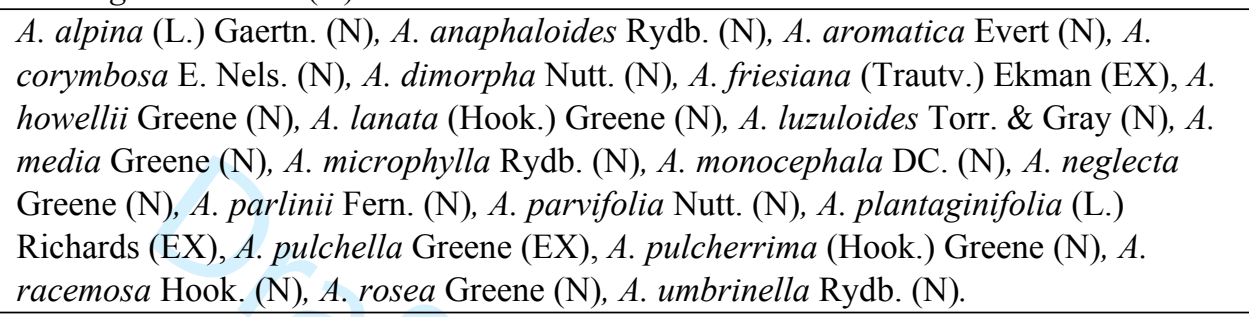 \\
\hline & Gamochaeta & G. purpurea (L.) Cabrera (N). \\
\hline & Gnaphalium & G. palustre Nutt. (N), G. uliginosum L. (I). \\
\hline & Logfia & L. arvensis L. (I). \\
\hline & Pseudognaphalium & P. macounii (Greene) Kartesz (N), P. thermale (E. E. Nelson) G. L. Nesom (N). \\
\hline & Psilocarphus & P. brevissimus Nutt. (N), P. elatior Gray (EX). \\
\hline \multirow{4}{*}{ Helenieae } & Gaillardia & G. aristata Pursh (N), G. pulchella Foug. (I). \\
\hline & Helenium & H. autumnale L. (N). \\
\hline & Hymenoxys & H. richardsonii (Hook.) Cockerell (N). \\
\hline & Tetraneuris & T. acaulis $($ Pursh) Greene $(\mathrm{N})$ \\
\hline \multirow{5}{*}{ Heliantheae } & Ambrosia & $\begin{array}{l}\text { A. acanthicarpa Hook. (N), A. artemisifolia Meyen \& Walp. (N), A. psilostachya DC. } \\
\text { (I), A. trifida L. (N). }\end{array}$ \\
\hline & Balsamorhiza & B. sagittata (Pursch) Nutt. (N). \\
\hline & Cyclachaena & C. xanthiifolia Nutt. (N). \\
\hline & Echinacea & E. angustifolia DC. (N). \\
\hline & Galinsoga & G. parviflora Cav. (I), G. quadriradiata Ruiz \& Pav. (I). \\
\hline
\end{tabular}




\begin{tabular}{|c|c|c|c|}
\hline & & Helianthus & $\begin{array}{l}\text { H. annuus L. (N), H. giganteus L. (EX), H. laetiflorus Pers. (EX), H. maximiliani } \\
\text { Schrad. (N), H. nuttallii Torr \& A. Gray (N), H. pauciflorus Nutt. (N), H. petiolaris } \\
\text { Nutt. (N), H. tuberosus L. (N). }\end{array}$ \\
\hline & & Heliopsis & H. helianthoides L. Sweet (N). \\
\hline & & Iva & I. axillaris Pursh $(\mathrm{N})$. \\
\hline & & Ratibida & R. columnifera (Nutt.) Wooton \& Standl. (N). \\
\hline & & Rudbeckia & R. laciniata L. (N), R. hirta L. (N). \\
\hline & & Xanthium & X. spinosum L. (EP), X. strumarium L. (N). \\
\hline & Inuleae & Inula & I. helenium L. (N). \\
\hline & Madieae & Arnica & 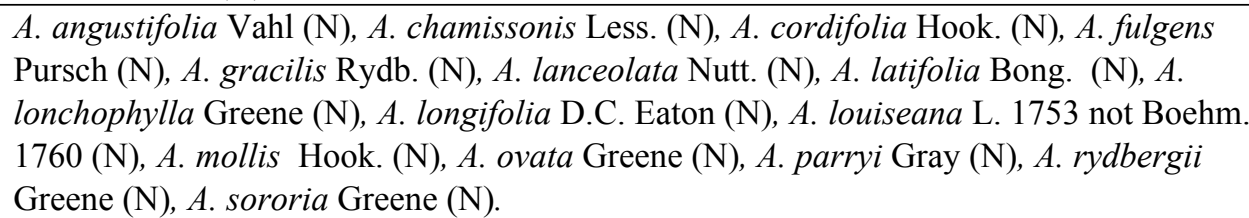 \\
\hline & & Madia & M. glomerata Hook. (I). \\
\hline & \multirow{6}{*}{ Senecioneae } & Erechtites & E. hieraciifolius (L.) Raf. ex DC. (EX). \\
\hline & & Jacobaea & J. vulgaris Gaert (I). \\
\hline & & Packera & $\begin{array}{l}\text { P. aurea (L.) A. \& D. Löve (N), P. cana (Hook.) W.A. Weber \& A. Löve (N), P. } \\
\text { contermina (Greenm.) Bain (N), P. heterophylla (Fishc.) Wieb. (N), P. hyperborealis } \\
\text { (Greenm.) A. \& D. Löve (EX), P. indecora (Greene) A. \& D. Löve (N), P. pauciflora } \\
\text { (Pursch) A. \& D. Löve (N), P. paupercula (Michx.) A. \& D. Löve (N), P. plattensis } \\
\text { (Nutt.) W.A. Weber \& A. Löve (N), P. pseudaurea (Rydb.) W.A. Weber \& A. Löve } \\
\text { (N), P. streptanthifolia (Greene) A. \& D. Löve (N), P. subnuda (DC.) D.K. Trock \& } \\
\text { T.M. Barkely (N), P. tridenticulata (Rydb.) W.A. Weber \& A. Löve (EX). }\end{array}$ \\
\hline & & Petasites & P. frigidus (L.) Fries (N). \\
\hline & & Senecio & $\begin{array}{l}\text { S. eremophilus Rich. (N), S. fremontii Torr. \& A. Gray (N), S. hydrophiloides Rydb. (N), } \\
\text { S. integerrimus } \text { Nutt. (N), S. lugens Rich. (N), S. megacephalus Nutt. (N), S. triangularis } \\
\text { Hook. (N), S. viscosus } \\
\text { L. (I), S. vulgaris L. (I). }\end{array}$ \\
\hline & & Tephroseris & T. palustris (R.Br.) DC. (N). \\
\hline & Tageteae & Dyssodia & D. papposa Cav. (I). \\
\hline \multirow{4}{*}{ Carduoideae } & \multirow{4}{*}{ Cardueae } & Arctium & $\begin{array}{l}\text { A. lappa L. (I), A. minus (Hill) Bernh. } 1800 \text { not Schkuhr } 1803 \text { (I), A. tomentosum Mill. } \\
\text { (I). }\end{array}$ \\
\hline & & Carduus & C. nutans L. (I). \\
\hline & & Carthamus & C. tinctorius L. (I). \\
\hline & & Centaurea & C. cyanus L. (I), C. diffusa Lam. (I), C. solstitialis L. (I), C. stoebe L. (I). \\
\hline
\end{tabular}




\begin{tabular}{|c|c|c|c|}
\hline & & Cirsium & $\begin{array}{l}\text { C. arvense (L) Scop. (I), C. discolor (Muhl. ex Willd.) (N), C. drummondii Torr. \& A. } \\
\text { Gray (N), C. flodmanii (Rydb) Arthur (N), C. foliosum (Hook.) DC. (N), C. } \\
\text { hookerianum Nutt. (N), C. muticum Michx. (N), C. scariosum Nutt. (N), C. undulatum } \\
\text { (Nutt.) Spreng. (N), C. vulgare (Savi) Ten. (I). }\end{array}$ \\
\hline & & Echinops & E. sphaerocephalus L. (EP). \\
\hline & & Onopordum & O. acanthium L. (EX). \\
\hline & & Rhaponticum & R. repens L. Hidalgo. (I). \\
\hline & & Saussurea & $\begin{array}{l}\text { S. amara L. (EX), S. americana D.C. Eaton. (N), S. angustifolia, Willd. DC (N). S. nuda } \\
\text { Ledebour. Icon. (N). }\end{array}$ \\
\hline & & Silybum & S. marianum L. Gaertn. (I). \\
\hline \multirow{17}{*}{ Cichorioideae } & \multirow{17}{*}{ Cichorieae } & Agoseris & $\begin{array}{l}\text { A. glauca (Pursh) Raf. var. agrestis (Osterh.) (EX), A. aurantiaca (Hook.) Greene (N), } \\
\text { A. glauca (Pursh) Raf. (N), A. parviflora (Nutt.) D. Dietr. (EX). }\end{array}$ \\
\hline & & Askellia & A. elegans (Hook.) W.A. Weber, 1984 (N), A. pygmaea W.A. Weber (N). \\
\hline & & Cichorium & C. endivia L. (EX), C. intybus L. (I). \\
\hline & & Crepis & $\begin{array}{l}\text { C. atribarba A. Heller (N), C. capillaris (L.) Wallr. (I), C. intermedia A. Gray (N), C. } \\
\text { modocensis E. Greene (EX), C. occidentalis Nutt. (N), C. runcinata (James) Torr. \& A. } \\
\text { Gray (N), C. tectorum L. (I). }\end{array}$ \\
\hline & & Helminthotheca & H. echioides (L.) Holub (I). \\
\hline & & Hieracium & $\begin{array}{l}\text { H. albiflorum (Hook.) F.W. Schultz \& Sch. Bip. (N), H. scouleri F.W .Schultz \& Sch. } \\
\text { Bip. (N), H. umbellatum L. (N). }\end{array}$ \\
\hline & & Krigia & K. biflora (Walter) S.F.Blake $1915(\mathrm{~N})$. \\
\hline & & Lactuca & $\begin{array}{l}\text { L. canadensis L. (EX), L. floridana (L.) Gaertn. } 1791 \text { (N), L. ludoviciana (Nutt.) Riddell } \\
1835 \text { (N), L. sativa L. (EX), L. serriola L. (I), L. virosa L. } 1753 \text { not Thunb. } 1800 \text { nor } \\
\text { Luce nor Hablitz (EX). }\end{array}$ \\
\hline & & Lapsana & L. communis L. (I). \\
\hline & & Lygodesmia & L. juncea (Pursh) D. Don ex Hooker (N). \\
\hline & & Microseris & M. nutans (Hook.) Sch. Bip. (N). \\
\hline & & Mulgedium & M. pulchellum (Pursh) G. Don (N). \\
\hline & & Nabalus & $\begin{array}{l}\text { N. alatus Hook. (1833) (N), N. albus (L.) Hook. (N), N. racemosus (Michx.) Hook } \\
(1833)(\mathrm{N}) \text {, N. sagittatus (A. Gray) Rydb. }(1900)(\mathrm{N}) .\end{array}$ \\
\hline & & Nothocalais & N. cuspidata (Pursh) Greene (N). \\
\hline & & Pilosella & $\begin{array}{l}\text { P. aurantiaca (L.) F.W. Schultz \& Sch. Bip. (I), P. caespitosa (Dumort) P.D. Sell \& C. } \\
\text { West (I), P. tristis (Willd. ex Spreng.) F.W. Schultz \& Sch. Bip. (N). }\end{array}$ \\
\hline & & Shinnersoseris & S. rostrata (A. Gray) Tomb (N). \\
\hline & & Sonchus & S. arvensis L. (I), S. asper (L.) Hill 1769 (I), S. oleraceus L. 1753 not Wall. 1831 (I). \\
\hline
\end{tabular}




\begin{tabular}{|c|c|c|c|}
\hline & & Stephanomeria & S. runcinata Nutt. (N), S. tenuifolia (Torrey) H.M. Hall (N). \\
\hline & & Taraxacum & $\begin{array}{l}\text { T. ceratophorum (Ledeb.) Schinz ex Thellung (N), T. erythrospermum Andrz. ex Besser } \\
\text { (I), T. lapponicum Kihlman ex Handel-Mazzetti (EX), T. officinale (L.) Weber ex } \\
\text { F.H.Wigg. (I), T. scopulorum (A. Gray) Rydb. (N). }\end{array}$ \\
\hline & & Tragopogon & T. dubius Scopoli (I), T. porrifolius L. (I), T. pratensis L. (I). \\
\hline & Vernonieae & Vernonia & V. fasciculata Michx. (N). \\
\hline Mutisioideae & Mutisieae & Adenocaulon & A. bicolor Hook (N). \\
\hline
\end{tabular}


Table 2. Asteraceae species present in the Prairie region which appear in Health Canada's NHPD monographs.

\begin{tabular}{|c|c|c|c|c|}
\hline Species & Status & Traditional Uses & $\begin{array}{c}\text { Active } \\
\text { phytochemical(s) }\end{array}$ & $\begin{array}{c}\text { Phytochemical } \\
\text { Reference }\end{array}$ \\
\hline Arctium lappa L. & Introduced & Diuretic and pain relief & $\begin{array}{l}\text { Arctigenin and } \\
\text { onopordopicrin }\end{array}$ & $\begin{array}{l}\text { (Hyam et al., 2013, de } \\
\text { Almeida et al., 2012) }\end{array}$ \\
\hline Artemisia vulgaris L. & Introduced & $\begin{array}{c}\text { Stimulates bile } \\
\text { secretion and appetite, } \\
\text { aids digestion }\end{array}$ & Apigenin & (Omar et al., 2019) \\
\hline Cichorium intybus $\mathrm{L}$. & Introduced & $\begin{array}{c}\text { Prebiotic and digestive } \\
\text { health aid }\end{array}$ & Chicoric acid & (Street et al., 2013) \\
\hline $\begin{array}{c}\text { Echinacea angustifolia } \\
\text { DC. }\end{array}$ & Native & $\begin{array}{l}\text { Relief of upper } \\
\text { respiratory tract } \\
\text { infections and sore } \\
\text { throat }\end{array}$ & $\begin{array}{l}\text { Echinacoside and } \\
\text { cynarine }\end{array}$ & (Linde et al. 2006) \\
\hline Helianthus annuus L. & Native & $\begin{array}{c}\text { Cholesterol } \\
\text { management }\end{array}$ & $\begin{array}{c}\text { Oleic and linoleic acids, } \\
\text { phytosterols }\end{array}$ & $\begin{array}{l}\text { (Adeleke and Babalola, } \\
2020)\end{array}$ \\
\hline Helianthus tuberosus L. & Native & $\begin{array}{l}\text { Relieves digestive } \\
\text { irregularity }\end{array}$ & Inulin & (Srinameb et al., 2015) \\
\hline $\begin{array}{c}\text { Matricaria chamomilla } \\
\text { L. }\end{array}$ & Introduced & $\begin{array}{l}\text { Relief of mouth/throat } \\
\text { irritation and } \\
\text { inflammation }\end{array}$ & $\begin{array}{l}\text { Apigenin-7-glucoside } \\
\text { and luteolin-7-O-B-D- } \\
\text { glucoside }\end{array}$ & (Haghi et al., 2014) \\
\hline $\begin{array}{l}\text { Silybum marianum L. } \\
\text { Gaertn. }\end{array}$ & Introduced & $\begin{array}{l}\text { Hepatoprotectant and } \\
\text { relief of indigestion }\end{array}$ & Silymarin & (Bijak, 2017) \\
\hline $\begin{array}{c}\text { Tanacetum parthenium } \\
\text { L. Sch.-Bip }\end{array}$ & Introduced & $\begin{array}{c}\text { Digestive aid and } \\
\text { migraine relief }\end{array}$ & $\begin{array}{l}\text { Parthenolide and other } \\
\text { sesquiterpene lactones }\end{array}$ & (Pareek et al., 2011) \\
\hline
\end{tabular}


Figure 1
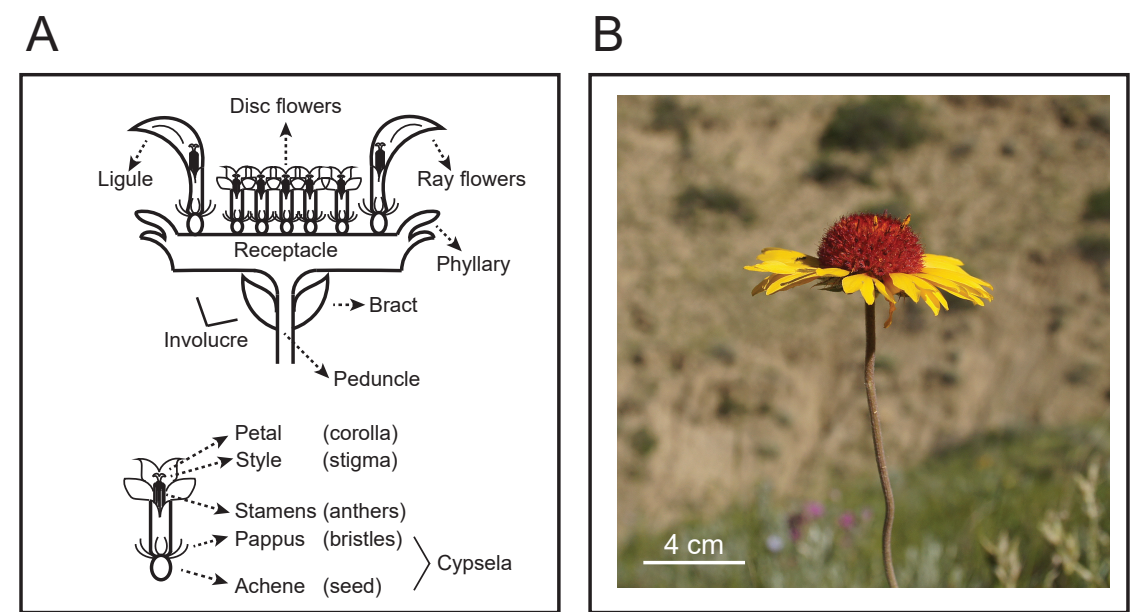

C

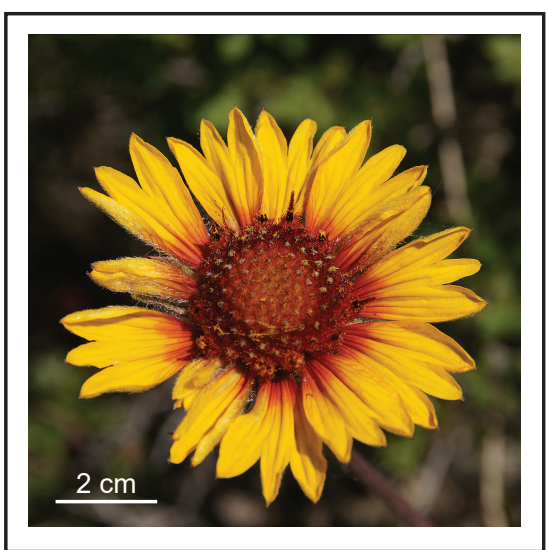




\section{Figure 2}

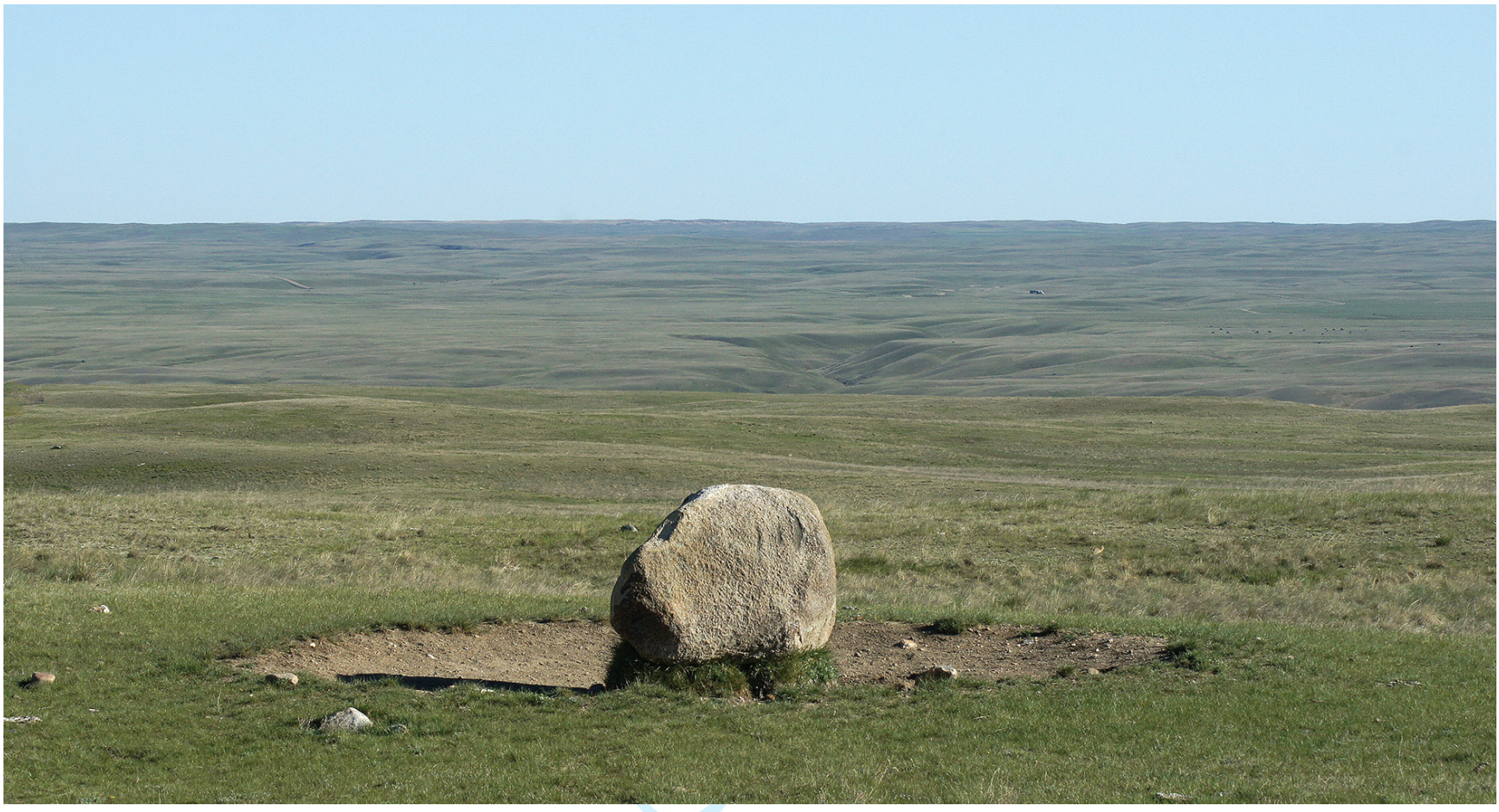


Figure 3

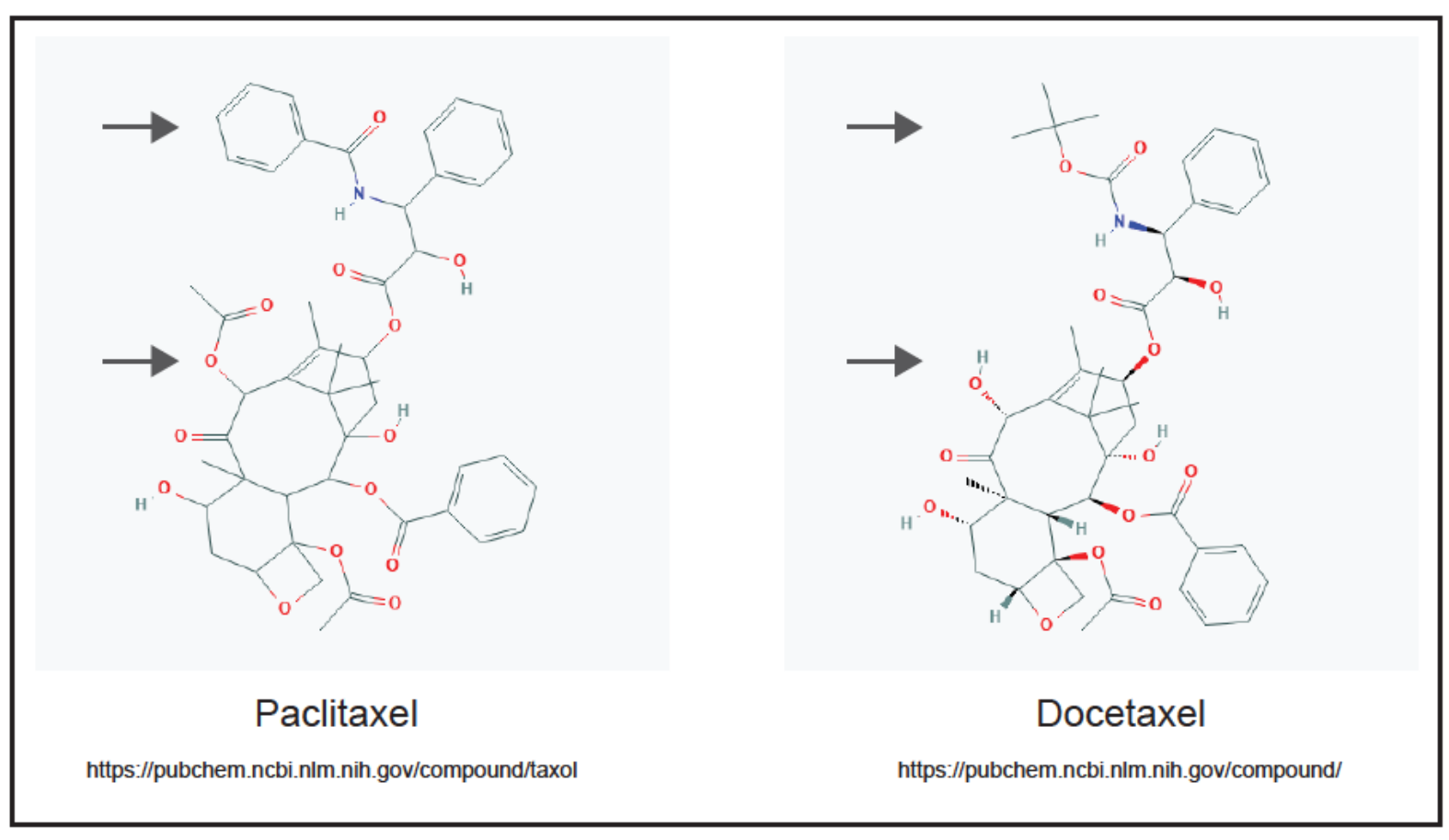

